\title{
An Evaluation of The Effectiveness of Teachers' Professional Development (TPD) in Iran using Akker Spider Web Model
}

\author{
Fouzieh Sabzian \\ (Corresponding author) \\ School of Educational Studies, University Science Malaysia, Malaysia \\ E-mail: f.sabzian@gmail.com \\ Zurida Ismail \\ School of Educational Studies, University Science Malaysia, Malaysia \\ Email: zurida@usm.my \\ Shaik Abdul Malik Mohamed Ismail \\ School of Educational Studies, University Science Malaysia, Malaysia \\ Email: smalik@usm.my \\ Kourosh Fathi Vajargah \\ Shahid Beheshti University, Iran, Tehran \\ Email:kfathi@sbu.ir
}

\author{
Accepted: Feb 16, 2013 Published: March 03, 2013 \\ Doi:10.5296/ijhrs.v3i3.4218 URL: http://dx.doi.org/10.5296/ijhrs.v3i3.4218
}

\begin{abstract}
Teaching is a complex job, involving classroom management, lesson's preparation and organization of teaching and learning process, creating and keeping a certain climate, evaluation and feedback. there is consensus on what composes good teaching while teachers have a vital role to any endeavor to grow education. Of course it is very important that not all teachers are effective. The role of the teacher as the exclusive holder of expert knowledge is being worn away by communication technologies. As the social framework of society is changing, the educative role of teachers becomes more complex. Teachers are one of the important foundations of all educational systems. In many countries, extensive programs like maintaining and building good teachers have turned into a fundamental strategy. In fact, teachers' roles and functions are relatively similar in most countries. Usually, teachers are expected to possess all the scientific and technical merits, to dominate course contents and apply appropriate methods and techniques for training, in order to be an appropriate model to
\end{abstract}


educate the youngsters.

This paper shows how stakeholders identify the strengths and deficiencies of teachers' professional development (TPD) with respect to in-service training and according to ten components of Akker Spider Web Model. The aims of this paper are to define evaluation, elaborate educational system in Iran, clarify teacher education, describe effectiveness teachers' professional development, explain teaching, state the necessity of evaluation, discuss the necessity of teachers' training and describe of ten components of Akker Model.

Keywords: Evaluation; effectiveness; teachers' in-service training; continuous professional development; Akker's spider web model.

\section{Introduction}

At the present time, It is not possible to find an organization which does not deal with professional development of its employees. Almost all job applicants require holding some sort of academic or technical certificates to be employed for a certain position they are applying for. In addition taking in to consideration the diversity of job variety, the scope of development and basic human learning limitations, the abilities and skills of people increasingly become out of date in professional areas. This trend led to occupation inadequacy in the contemporary organizations.

For this reason training and development of staff has become one of the main concerns of the managers in the organizations and a variety of institutes. All the effective managers are dealing with the professional development of their employees as one of the most critical and important aspects of their jobs. In the other word, as reaching to organizational goals makes it necessary to go along with the changes in procedures, techniques and administration tools, professional development of employees has been received much more attention in the recent decades. This is to say that staff development need to consider a major enterprise in all organization. In order to reach these objectives, defining training needs, program development, resources providing and facilitating the program implementation are considered important and critical organizational challenges (Abtahi, 1989).

\section{Definition of teachers' professional development}

Every action which enhances the skills, knowledge or understanding between teachers, and their effectiveness in schools were called professional development. It is the whole thing that the teachers do to stay progress and remain up to date, starting with training on their job thoroughly (DfES, 2000).

In fact, professional development is one of the major concerns in the contemporary era and some researchers like Guskey (1995) believes that nowadays, the calendar and history of education cannot show a bigger identification of the value of professio nal development.Every new plan needs to be changed, reorganize, or even renovating schools to emphasize 
professional development as a main vehicle. On the other hand, by means of this enlarged recognition, the examination grade shows an improvement. Numbers of subjects have been increased according to the effectiveness of all shapes of professional development in education. Furthermore, these subjects have higher expectations for provable results. All the societies' members such as, politicians, legislator, funding agencies, and the general public would like to know if this professional development program really makes a difference.

Dean (1991) showed professional development as a process which teachers turn into much more professional. A piece of this development is the combining of particular skills, knowledge and understanding. Thus, professional development can be seen as an increase in some portion of professionalism and can correctly be used for the development of people or groups if the rationale of the movement is to develop the professionalism. Professional development is higher than all, about confirming the experience for students in the classroom. It is concerned to give advantages to everybody in the educational system especially schools. In terms of professional development performances set from short-term, single-shot courses' experiences to multiyear programs. A number of teacher enrichment programs have a short term workshop in which a specific method is described or a new strategy introduced. Another one is a long term workshop that it is lasted some weeks in duration and may perhaps consist of year-round proceedings activities. And also there are programs founded on multi-year set-up, where teachers go through the levels of training (Frechtling et al, 1995).

\section{Educational System in Iran}

Islamic Republic of Iran as a developing country has an enormous historical background and a rich civilizing inheritance and also has experienced a lot of ups and downs throughout the centuries so far. In connection with area at $1,648,195 \mathrm{~km}^{2}$, Iran is the $18^{\text {th }}$ biggest country in the world and it has a population of around 78 million (Statistical Centre in Iran, SCI, 2010). In the last two decades, Iran's population has been rising at a shocking speed. Iran population went above 70 million and it is upward at $1.5 \%$ annual rate (3.5\% in 1992). Almost two-thirds Iran's people are below 30 years old (MAI, 2005, Annual Report).

Tehran is the capital city of Iran, the country's largest city and the political, cultural, commercial and industrial centre of the nation and its population is 7, 705, and 036 . The population of Tehran, the urban area included the city, which is about 12 million (at night not day). Tehran has residences around $11 \%$ of Iran's population (Tauris, 2006).

Iran basically has a centralized educational system and the majority decisions on the management of all the educational levels (primary, second ary and high schools) are done at national level and the ministry of education. The level of K-12 education is organized by the Ministry of Education and the step of higher education is controlled by the Ministry of Science and Technology. Pre-primary school (Pish-Dabestani) starts at ages 4 and 5 for 2 years and this period is not compulsory as there is an optional choice for parents. Primary school (Dabestan) starts at the age of 6 for about 6 years. The Middle school, recognized as course series (Rahnamayi), starts from grade of seven to nine. High school (Dabirestan), for which the last three years is not obligatory, is categorized into academic, vocational/technical and Mathematic physical, with each program having its own fields (MoE, 2004). 
Universities, institutes of technology, medical schools, and public colleges, are at the higher educational level. A high school Diploma is required before pursuing higher education as well as the public University entrance exam (Konkoor). Higher education is certified by diverse levels of diplomas: For instance, Fogh-e-Diplom or Kardani after 2 years of higher education, Karshenasi (also known under the name "license") is obtained after 4 years of higher education (Bachelor Degree) Karshenasi-ye Arshad is gained after 2 more years of study (Master's Degree). Last but not least, a student needs to take an additional examination that permits the applicant to follow a Doctorate, doctoral $(\mathrm{PhD})$ program.

The system of education in Iran is a federated one; as a result, the program is developed by a national curriculum authority in fundamental organization and launches to school for carrying out. Teachers are mandated to apply the mandatory syllabus as approved by government. Neither teachers nor students are allowed to create modify in the plan; they do not have any role in program development. There is no chance for the stated representative to contrib ute in curriculum needs assessment and development (Fathi et al, 2010, P, 220).

The ultimate goal of the policy of Ministry of Education is to produce manpower and technocrat community that are able to compete in the international level and indirectly can contribute to the development of the country. To this end, schools have a responsibility to provide each pupil with these skills and knowledge competency necessary for their academic, economic and social growth. It is also the responsibility of Ministry of Education to provide well qualified teachers to deliver perfect instruction. In fact, teachers are the mediators between curricula, materials, educational goals, and the students.

The Ministry of Education in Iran as a specialized system carries the responsibility of managing and planning a variety of educational activities in all different levels. From organizational structure point of view, the system is the initiator and holder of (shared with other organizations) general and special training functions. The teachers employed by the Ministry of Education in order to work in schools, should have appropriate opportunities for professional development and being up-to-date in the constantly changing education system.

Although importance of professional development is a fully recognized by Iranian authorities in the recent years and there have been some activities and programs for teachers' development fragmentally, there are not enough evidences on systematic planning and administration on the professional de velopment of the teachers or at least it can said that there are strong concerns about the quality of such activities.

If in educational systems where teacher education activities were well established, teacher professional development is explained as a way embracing all programs that improve professional job growth (Rogan, 2004; Tecle, 2006) and as formal or informal experiences during the teacher's career (Hargreaves \& Fullan 1992; Arends et al. 1998). 


\section{Macrothink Institute ${ }^{\mathrm{TM}}$}

\section{Definition of teachers' in-service training}

The chances for teachers to achieve new skills, knowledge, approaches and dispositions in developing their classroom`s teaching and effectiveness. With respect to Sparks and Hirsch (1997) in-service training, professional development, and staff development should influence the knowledge, attitudes and practices of the trainee. In this study, the term in-service training, professional development, and staff development use alternatively to relate to the continuous learning activities. These terms are crucial to increase the teachers' professional confidence, personal education and desires, and also common understanding of their changing roles and tasks.

\section{Definition of Akker (2003) Model}

As can be seen, the Figure 1. depicts the Spider web 'Akker's Model (2003):

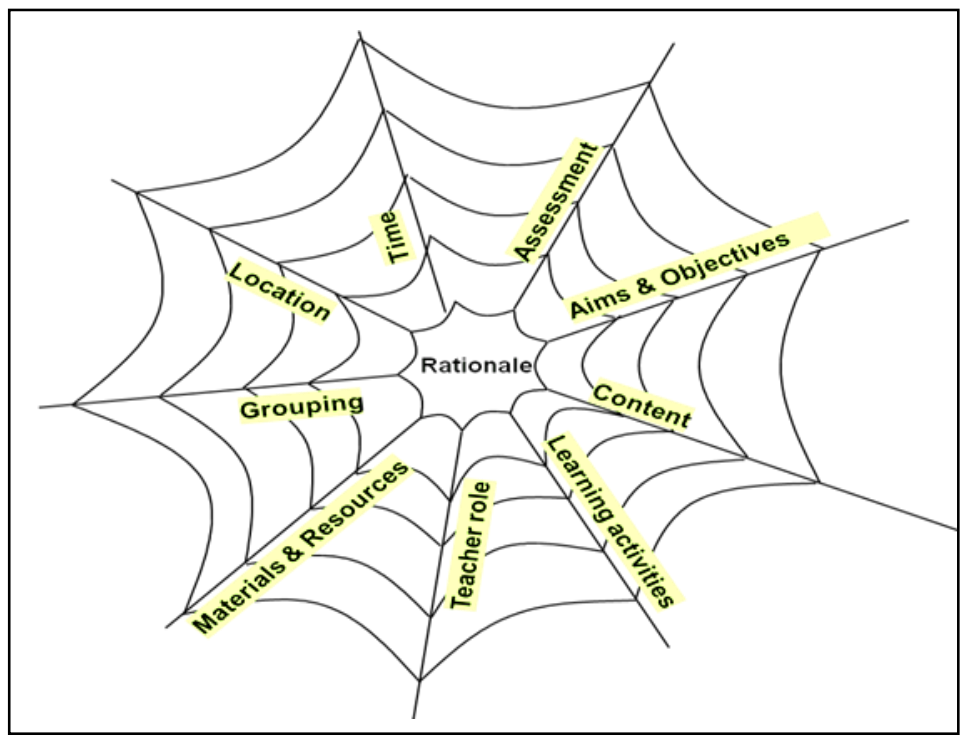

Figure1. Spider Web Model (Van den Akker, 2003)

As can be illaustrated, the Rationale is the body of the program and is based on the core of the web, surrounded by the different components: Aims and Objectives, Content, Learning activities, Trainer's role, Materials and Resources, Grouping, Time, Location, and Assessment. The core and the nine threads of the spider web refer to the ten parts of a plan, each concerning an aspect of learning and the learning program for teachers.

The rationale is to provide an essential link, related to all other components. Ideally, these are also connected to each other, giving firmness and coherence as well (Akker, 2003). Preferential visualization of the ten components are needed to arrange them as a spider web to illustrate not only its many inter-connections, but also underlining its vulnerability. Thus, although the emphasis of plan design on specific components may vary over time, eventually some kind of alignment has to occur to maintain coherence. The spider web also illustrates a familiar expression: 'every chain is as strong as its weakest link'. That seems 
another very appropriate metaphor for the program, pointing to the complexity of efforts to improve the training program in the teacher training system (Akker et al, 2010).

Akker's model actually prefers to arrange these ten components in shape of a spider web; a visualisation that demonstrates not only their interconnectivity but also their vulnerability, this is illustrative of the expression that 'every chain is as strong as its weakest link'. Although in design these components may receive attention at different stages, eventually they need to show some kinds of alignment to maintain coherence(Akker, 2003).

Table 1. Program Components of Akker(2003)Model

\begin{tabular}{|l|l|}
\hline COMPONENT & \multicolumn{1}{|c|}{ QUESTION } \\
\hline 1- Rational & Why are they learning? \\
\hline 3- Content & Toward which goals are they learning? \\
\hline 4- Learning Activities & What are they learning? \\
\hline 5- Trainers' Role & How are they learning? \\
\hline 6- Materials \& Resources & How is the teacher facilitating learning? \\
\hline 7- Grouping & With what are they learning? \\
\hline 8- Location or place & With whom are they learning? \\
\hline 9- Time & Where are they learning? \\
\hline 10- Assessment \& Evaluation & When are they learning? \\
\hline
\end{tabular}

Ten components of Akker(2003)Model

\section{Concepts and Dimension of Professional Development}

Bolam (1986) stated that, there are five major reasons of continuing education for teachers. First of all, it is to recover the occupation activities skills of the total teams of the school personnel. The second reason is to advance the career performance skills of a teacher. The next reason is expanding the experience of an individual teacher for job improvement and continued by this reason which is developing the professional knowledge of a person teacher. The final reason is enlarging the staff education of a person.

In addition, some researchers (Yarger et al., 1980) have indicated this holistic approach; they are referring to five forms in-service training. First of all is job-embedded, which focuses in 
hands-on experience to improve teaching skills while working with pupils. The second form is job-related, that is directly connected to the job, but does not happen throughout the teaching. The next form is generally professional, which includes experiences to develop general abilities, with the directly particular needs as the preceding experiences. Fourth is a profession permitted, which make an individual able to attain a new credential or get ready for a new responsibility. The last form is individual that facilitates development that can or cannot relate to teaching.

According to West-Burnham and O'Sullivan, (1998), professional development is the essential element in improving both skill and knowledge. It would be impossible to increase children`s achievement without increasing teacher's ability, but professional responsibility has to include a higher commitment to upgrade a professional learning process. The main factor, conceptual change in the background of increasing ability and growing accountability can be seen helps to emphasize on preventing failure than reacting to it.

Professional development, regarding to Grant (1994), consists of formal as well as informal learning ways of assisting teachers in getting new skills, improving new perceptions of education, and acquirement a new or progressive knowing of professional content and resources. While later Bubb (2004) refers to the continuing professional development (CPD) which surrounds by all formal and informal learning that facilitate people to promote their own performance. 'Staff development' and 'in-service training' means that they may take place, but 'continuing professional development' (CPD) is similar to a big umbrella term to express every part of the professional development.

Continuing professional development(CPD) is an enormous domain. Bolam (1993) drew a practical difference between 'professional education', 'professional training' and 'professional support'. The first area is 'professional education' which including long-courses and secondment focusing on theory and research-based knowledge. The second one is 'professional training' which contains short-courses, workshops, conferences focusing on useful information and skills and the last is 'professional support' which insists on the performance that plan to extend on the job experience and activities.

In 2003, Partington et al., declared that, some phrases as 'staff development', 'continuing professional development', 'training' and 'lifelong learning'; all should exactly explained for their different meanings. 'Staff training'suggests the gaining or expansion of necessary skills that raise teachers to a demanded range of proficiency. 'Continuing professional development' is the expression which has turn usually into applied continuous education and training for the jobs.

Some researchers such as Earley and Bubb (2004) are the pioneers in this area as the actual professional is still learning during working. Professional development shows a very important position in school improvement where it emphasizes to consider activities in the system to have an advance education by providing the knowledge and skills to teachers. 


\section{Evaluation}

Mirkamali (1994) believed that evaluation means determining the positive or negative parts of conducted tasks. Furthermore, a process used to determine what has occurred throughout a given activity or an organization. The purpose of evaluation is to see if a given program is working, if an institution is successful according to the goal set for it, or if the original aim is being successfully carried out to assessment, evaluation adds the component of value judgment of the social value, desirability, or effectiveness of a program, product or process, and it sometimes includes a suggestion for some course of action (Best \& Kahn, 2008).

There are several evaluation "levels," ranging from basically providing information on participants' reactions to the training- the effectiveness of the teacher or trainer, the relevance of the contents, the quality of the materials- to measure the conclusions or results of the training program (World Bank Institute, 2008).

According to Farell et al (2002) approximately every day of individual lives' they usually make judgments concerning the environment around them. Basically, whether they distinguish it or not, they are involved in the process of evaluation.

In general, evaluation is one of the most essential components of reasonable professional services. The customers of professionals earn support that is aimed to meet their wants, of high quality, up-to-date, and efficient. A number of the evaluation work which is directed to the instruction should be conducted by independent organizations, similar to government agencies and accrediting boards. But basically, the most important evaluation of professional services are conducted or commissioned by professional themselves (Stufflebeam \& Shinkfield, 1985).

About the importance of evaluation, one description is related to Stufflebeam \& Shinkfield, (1985); evaluation is the organized assessment of the value or merit of some object. This definition focuses on the root-term importance and indicates that basically evaluation involves judgment. While evaluation optimally uses an objective procedure with the purpose of finding dependable and unbiased information, it is not value-free. If a study does not report how good or bad something is, it is not evaluated.

An important part of the evaluation process is the understanding of principles and elements that contribute to a successful design (Gordon, 2008, p, 39). This is supported by Stronge et al. (2011) who point out, efficiency is an intangible impression to identify when people believe the complex job of teaching and the multitude of contexts in which teachers work. When talking about teachers ' training and the qualities of teachers' effectiveness, Lewis et al. (1999) appropriately quoted that "quality of teachers is a complex phenomenon, and there is a little compromise on what it is or how to evaluate it".

In other word, Stronge et al (2011) as serts that, a better perception of what comprises teacher efficiency has significant implications for decision making regarding to preparation, recruitment, compensation, in-service professional development, and evaluation of teachers.

As at the present, a large amount of human and financial resources are allocated for administrating such training courses annually, it is necessary to use all resources effectively 
in order to achieve to the desired professional development goals of teachers in primary education.

Thus the aim of the present research is conducting a comprehensive review of this professional development system of teachers and recognizing the challenges, and inadequacies, and suggesting effective strategies for re redesigning of professional enhancement system of elementary schools.

\section{Program Evaluation}

In relation to program evaluation and before investigating the definition of these terms, let's look at the short explanation of the term program. A 'program' is a set of activities designed to achieve something valuable to a system. Philips (1997) declared the program considered as "a series of courses or learning solutions, or other proceedings that are educational or developmental in nature". With respect to Worthen, (1990) a program in an educational environment is an activity meant to solve a specific educational problem or to improve a future of the educational organization itself.

It is necessary to mention that from Anderson et al. (1978) points of view, the purposes of program evaluation are contributing to decisions on program installation, continuation, growth, certification, and change or understanding basic psychology, social and other processes; and gathering evidence to support or oppose a program. Just as Rossi et al.(1999) have stated, program evaluation uses research procedures to investigate systematically the efficiency of social interference programs that are adapted to their political and organizational environment and designed to inform social action in methods that can improve social conditions. It would be possible that, program evaluation can be a very useful tool for professionals who are interested in maximizing the potential for human resource programs as a value-added purpose inside the system. Also, it can be used to find out the value of programs that have been, or being applied; clearly considers the alternative interferences accessible; and contains an assessment of economic effects .

This thinking is corroborated by some researchers such as Rose and Davidson (2003); they believe that a well-conducted evaluation can be used to distinguish between interventions that make a meaningful contribution to an organization's competitive advantage. Program evaluation is valuable for decision makers whether to modify an existing program or abolish an existing program; or choosing another program that become more efficient to achieve great objectives.

\section{Conclusion}

Education is one of the major difficulty concerns in human life and there has constantly been an agreement regarding its need and significance. However diverse ways have been followed because of the shortage of consensus related to their elements, features, quality and quantity in the current decade. There are various cultural, economic, social and political aspects in different countries and each society has its own context as well as social, political, cultural and economic foundation. Therefore, approaches to the subject of educational principles, 
specifically what they should be actually, are diverse and, sometimes, conflicting (Fathi, 2000).

Guskey (1995) belived that professional development is one of the most important concerns in the contemporary era. At the present time, the calendar and history of education cannot show a bigger identification of the importance of professional development. All new plan needs to be changed, reorganize, or even renovating schools to emphasize professional development as a main vehicle. In a sense, by means of this increased recognition, the examination grade shows an improvement. Various subjects have been enlarged according to the effectiveness of all shapes of professional development in education. The speed of changes and the explosion of knowled ge necessitate people to learn a fresh period of time through their life. The heaviness on the responsibility and anxiety of struggle has also set a bigger stress on the need for teachers to grow and learn rapidly. Good teaching is not likely to come about by chance and accidentally. New modes of behaviour develop when particular actions are repeated and trained again and practiced again as long as they become an organic part of the individual.

\section{Acknowledgement}

We would like to thank Alireza Pourebtehaj, Zoha Pourebtehaj and Sedigheh Sodouri for their extensive and insightful supporting and comments on this paper.

\section{References}

Abtahi,H. (1989). Education and Human Resourse Development.Tehran,Institute of Educational Planning Studies.

Anderson, S. B. \& Ball,S. (1978) The profession and practice of program evaluation.San Francisco:Jossey- Bass.

Arends, R. I., Winitzky, N. E. \& Tannenbaum, M. D. (1998). Exploring Teaching. New York: McGraw Hill.

Best J, W. \& Kahn, J.V (2008) Research in Education (10 ${ }^{\text {th }}$ ed.)Needham Heights, A: Allyn \& Bacon

Bolam, R. (1986). Conceptualising in-service. In D. Hopkins(Ed.), in-service training \& educational development: An international survey. (pp,14-34). London :Croom Helm

Bolam ,R. (1993) 'Recent Developments and Emerging Issues"in The Continuing Professional Development of Teachers.London:GTC.

Bubb, S. (2004). Early Professional Development. London, Routledger Falmer 11 New Fetter Lane.

Dean , J. (1991). Professional development in school. Milton Keynes, Philadelphia: Open University Press.

DfES,(Department of Education \& Eployment)(2000)Professional Development: Support for Teaching and Learning.London:DfEE.

Early,P.\& Bubb,S.(2004)Developing Teachers, Developing Schools: Making Continuing Professional Development Work.London:Sage/Paul Chapman 
Fathi, Vajargah, K, (2000), Standard School. Tehran. Fakher Publications, (pp. 22-23).In Persian

Fathi, Vajargah., K,.M, Abolghasemi \& ,N, Askari (2010). "The Pathology of Research Management System in National Iranian Drilling Company." World Applied Sciences Journal 8 (9) 1129-1135.

Farell ,K.,M. Kratzmann ,S. McWilliam ,N. Robinson ,S. Saunders ,J. Ticknor,K.White (2002)Evaluation Made very easy accessible and logical, Atlantic Centre of Excellence for Women's Health ,PO Box 3070 ,Halifax, Nova Scotia B3J 3 G9.

Frechtling, J. A., Sharp, L., Carey, N., \& Vaden-Kiernan, N. (1995). Teacher Enhancement Programs: A Perspective on the Last Four Decades, Westat.

Gordon, K, W. (2008) 'Curriculum Evaluation of Technical Vocational

Training', (A Case Study) Unpublished Doctoral dissertation, University of Nottingham

Grant, C. (1994). Best practices in teacher preparation for urban schools. Actions in Teacher Education, 16, 1-18.

Guskey, T. R. (1995) Results-oriented professional development:; in search of an optimal mix optimal mix of effective practices, University of Kentucky.

Hargreaves, A. \& Fullan M. G. (Eds.) (1992). Understanding Teacher Development. New York: Teachers College Press.

Lewis, M. D., Lamey, A. V., \& Douglas, L. (1999). A new dynamic systems method for the analysis of early socioemotional development. Developmental Science, 2, 458-476.

MAI, (2005). Annual Report. Tehran: Iranian National Center for Statistics (MAI). MAI Publications.

Ministry of Education, (2004) Bureau of International and Scientific Cooperation. National report on the development of education of The Islamic Republic of Iran. International Conference of Education, $47^{\text {th }}$ session, Geneve.

Mirkamali, M. (1994) Management in mainstream education Quarterly article of "philosophy of evaluation in management" No 4. Third year serial No 12 .

Partington, P. \& Stainton, C. (2003). Managing staff development. Buckingham and Philadelphia: Open University Press.

Philips, J.J. (1997). Handbook of training evaluation and measurement methods $\left(3^{\text {rd }}\right.$ ed.). Houston, TX: Gulf Publishing Company.

Rogan, J. (2004). Professional development: Implications for developing countries. In K. O-saki, K. Hosea \& W. Ottevanger, Reforming science and mathematics education in sub-Saharan Africa: Obstacles and opportunities (pp.155-170). Amsterdam: Vrije Universteit Amsterdam.

Rose, D.S. \& Davidson, E.J. (2003). Overview of program evaluation. In J.E.Edwards,J.C.Scott \& N.S.Raju (Eds), The human resource program-evaluation handbook,(pp.3-26). Thousand Oaks,CA:Sage Publications,Inc.

Rossi, P., Freeman, H., \& Lipsey, M. (1999). Evaluation: A systematic approach (6 ${ }^{\text {th }}$ ed.). Thousand Oaks, CA: Sage.

Sparks, D. \& Hirsh,S. (1997). A new vision for staff development. Alexandria, VA: Association for Supervision and Curriculum Development.

Stronge, J. H, Thomas J. Ward, \& Leslie W. Grant, (2011). What Makes Good Teachers Good? 
A Cross-Case Analysis of the Connection Between Teacher Effectiveness and Student Achievement, Journal of Teacher Education 62(4) 339- 355, http://www. sagepub.com/journalsPermis sions.nav DOI: 10.1177/0022487111404241

Stufflebeam, Daniel. L \& Shinkfield, Anthony .J (1985) Systematic Evaluation, A self-Instructional guide to theory and practice. Kluwer, Nijhoff Publishing, Boston, Dordrecht, Lancaster
Tauris,
I.
B.
(2006)
Persian
Empire,

http://www.imes.ed.ac.uk/index-pages/staff_pages/andrew_newman.html

Tecle, T. (2006). The Potential of Professional Development Scenario for Supporting Biology Teachersin Eritrea. Enschede: Print Partiners IPS Kamp.

Yarger ,S.J., Howey, K.R. \& Joyce, B.R. (1980). In-service teacher education. Palo Alto: Booksend Laboratory.

Van den Akker, J. (2003). Curriculum perspectives: An introduction. In J. Van den Akker, W. Kuiper, \& U. Hameyer (Eds.), Curriculum landscapes and trends (pp. 1-10). Dordrecht: Kluwer Academic Publisher.

Van den Akker,J.,B, Bannan,A, E. Kelly,N, Nieveen,T, Plomp(2010) An Introduction to Educational Design Research Proceedings of the seminar conducted at the East China Normal University, Shanghai (PR China). Inc Tj, Plomp \& N, Nieveen (eds)ISBN: 97890 329 2329

7,SLO,P.O.

www.slo.nl/organisatie/international/publications, Enschede,Netherlands

West-Burnham, J. \& O' Sullivan, F. (1998). Leadership \& professional development in schools: How to promote techniques or effective professional learning. London: Pearson Education Limired.

WBI, World Bank Institute (2008). Does Training Work? Re-examining

Countries. Capacity Development, Donor-Sponsored Training Programs in Developing,

Brief World Bank, Washington, DC.

Worthen, B.R. (1990). Program evaluation. In H. J. Walberg \& G. D. Haertel (Eds.), The international encyclopaedia of educational evaluation (pp.42-47).Oxford, UK: Pergamon Press. 